\title{
华北低丘山区果药复合系统种间水分利用策略
}

\author{
何春霞 1,2 陈 平 1,3 孟 平 $1,2^{*}$ 张劲松 ${ }^{1,2^{*}}$ 杨洪国 1,2
}

${ }^{1}$ 中国林业科学研究院林业研究所, 国家林业局林木培育重点实验室, 北京 $100091 ;{ }^{2}$ 南京林业大学南方现代林业协同创新中心, 南京 $210037 ;{ }^{3}$ 河北 省水利水电勘测设计研究院, 天津 300250

摘 要了解林农复合系统的种间水分关系至关重要。该文通过稳定気同位素研究了华北低丘山区核桃(Juglans regia)-菘蓝 (Isatis tinctoria)/决明(Senna tora)复合系统各组分的水分来源, 试图明确该果药复合系统的种间水分利用策略, 为该区林农配 置模式的选择提供理论依据。研究结果表明: 果药复合系统的土壤含水量明显高于单作菘蓝和单作决明地块, 在 2012 年、2013 年上半年比单作菘蓝高 $26.74 \%$ 和 $7.93 \%$, 在下半年比单作决明高 $17.39 \%$ 和 $13.65 \%$ 。在果药复合系统内部, 土壤含水量以核桃 树行中间位置的最低、树行北侧和树下最高。在各个土层深度, 单作系统的土壤水氢稳定同位素比率 $(\delta \mathrm{D}$ 值)均比复合系统的 高。在菘蓝生长时期的春早期, 复合系统中核桃的大部分水分来源于 30-80 $\mathrm{cm}$ 深层土壤水, 表明此时期核桃表层根系活性不 高; 而决明生长时期正值雨季, 此时核桃优先利用雨水补充的 $0-30 \mathrm{~cm}$ 浅层土壤水、表层根系活性增强。在任何生长时期, 菘 蓝和决明 $85 \%$ 以上的水分都来自浅层土壤水。在菘蓝苗期, 其根系尚未扎入深层土壤中, 单作菘蓝的水分完全来源于浅层土 壤, 而在 2012 年间作菘蓝却有 $5.7 \%$ 的水分来自于深层土壤, 在更为干旱的 2013 年该比例上升到 $9.7 \%$, 该结果证实了核桃在旱 季存在“水力提升”作用, 供浅根系作物吸收利用, 并且越干旱, 该水力提升作用越强。在华北低丘山区核桃-菘蓝/决明复合系 统中, 深根性核桃改善了复合系统的土壤水分状况, 在旱季主要利用深层土壤水以避开与浅层作物的水分竞争、并能将深层 土壤水提升至浅层土壤供菘蓝吸收利用, 核桃与两种药材表现为水分互利关系, 因而该模式适合在该地区发展。

关键词 农林复合系统; 核桃; 菘蓝; 决明; 氢稳定同位素比率 $(\delta \mathrm{D})$; 种间水分关系

引用格式: 何春霞, 陈平, 孟平, 张劲松, 杨洪国 (2016). 华北低丘山区果药复合系统种间水分利用策略. 植物生态学报, 40, 151-164. doi: $10.17521 /$ cjpe. 2015.0360

\section{Interspecific water use strategies of a Juglans regia and Isatis tinctoria/Senna tora agroforestry system in a hilly area of Northern China}

\author{
HE Chun-Xia ${ }^{1,2}$, CHEN Ping ${ }^{1,3}$, MENG Ping ${ }^{1,2 *}$, ZHANG Jin-Song ${ }^{1,2 *}$, and YANG Hong-Guo ${ }^{1,2}$ \\ ${ }^{1}$ Key Laboratory of Tree Breeding and Cultivation, State Forestry Administration, Research Institute of Forestry, Chinese Academy of Forestry, Beijing 100091, \\ China; ${ }^{2}$ Co-Innovation Center for Sustainable Forestry in Southern China, Nanjing Forestry University, Nanjing 210037, China; and ${ }^{3}$ Hebei Re- \\ search Institute of Investigation \& Design of Water Conservancy \& Hydropower, Tianjin 300250, China
}

\section{Abstract}

Aims Understanding the interspecific water relations is important for designing agroforestry systems. The objective of this study was to determine the water use strategies of component species in a walnut (Juglans regia)-woad (Isatis tinctoria)/sicklepod (Senna tora) agroforestry system.

Methods Water sources of component species in a walnut-woad/sicklepod agroforestry system were investigated with the technique of stable deuterium isotope tracing at a site of hilly area in Northern China during 2012-2013.

Important findings Results showed that the soil water content in the agroforestry system was $26.74 \%$ and $7.93 \%$ greater than in the pure woad field in the first half year, and $17.39 \%$ and $13.65 \%$ greater than in the pure sicklepod field in the second half year (sicklepod growth period), in 2012 and 2013, respectively. The lowest water content was found in the middle of tree rows, and the highest water content was found in the northern side of tree rows or under the trees. In the soil layers measured, the pure woad and pure sicklepod systems had greater hydrogen stable isotope ratios ( $\delta \mathrm{D}$ value) of soil water than in the agroforestry system. During the period of woad growth, more than half of the water absorbed by walnut was from the deeper soil layer $(30-80 \mathrm{~cm})$. In contrast, the walnut trees mainly utilized shallow layer $(0-30 \mathrm{~cm})$ soil water during the period of sicklepod growth. These findings suggest that walnut has a two-state root system: during the period of woad growth, shallow roots of walnut are not active when soil is dry; whereas the sicklepod growth occur in rainy season, and the shallow roots of

收稿日期Received: 2015-10-11 接受日期Accepted: 2015-12-27

* 共同通信作者Co-author for correspondence (E-mail: mengping@caf.ac.cn; zhangjs@caf.ac.cn) 
walnut are active and utilize more shallow soil water supplemented by rainwater. More than $85 \%$ of water used by both the woad and the sicklepod were from the shallow layer soil. At the seedling stage, the roots of woad, cannot grow into the deeper soil layer, and the absorbed water is completely from the shallow layer in the pure woad system. However, $5.7 \%$ of the water absorbed by the intercropped woad was from the deeper soil layer in 2012, and the proportion increased further $(9.7 \%)$ in the following year when there was less precipitation. The results confirmed that hydraulic lift effect of walnut occurred on shallow layer crop in dry season, and this effect become greater under drier conditions. Therefore, deeper roots of walnut improved water condition in the walnutwoad/sicklepod agroforestry systems compared to pure crop systems. The walnut mainly utilized water from the deeper layer to avoid water competition with the shallow layer. In the dry season, crops benefited from the water provided by walnut roots through hydraulic lift. Walnut and intercropped plants exhibited water facilitation in the agroforestry systems, suggesting that this configuration is a suitable practice in this area.

Key words agroforestry system; walnut (Juglans regia); woad (Isatis tinctoria); sicklepod (Senna tora); hydrogen stable isotope ratio $(\delta \mathrm{D})$; interspecific water relation

Citation: He CX, Chen P, Meng P, Zhang JS, Yang HG (2016). Interspecific water use strategies of a Juglans regia and Isatis tinctoria/Senna tora agroforestry system in a hilly area of Northern China. Chinese Journal of Plant Ecology, 40, 151-164. doi: $10.17521 /$ cjpe. 2015.0360

华北低丘山区虽然地处半湿润暖温带地区，但 土层脊薄、土壤保水力差等劣质立地条件加上季节 性干旱等极端气候导致水分亏缺是该区生态脆弱性 的主要特征。同时灌溉条件差也严重制约了当地农 业的发展。为了保护脆弱的生态环境, 提高农民收 入, 当地发展了多种配置的林农复合系统。合理的 林木和作物配置能充分利用水肥光热等资源、提高 系统的生态及经济效益。已有较多研究证实农林复 合系统相比单作系统具有明显的产量优势, 如 Zhang等(2013)对新疆和田的疋(Zizyphus jujube)-小 麦(Triticum aestivum)复合系统、Rivest等(2010)对杨 树 $($ Populus nigra $\times$ P. maximowiczii)-大豆(Giycine $\max$ )复合系统, 以及孙守家等(2010)、Sun等(2014) 和何春霞等(2012)对核桃(Juglans regia)-绿豆(Vigna radiata)、核桃-小麦等复合系统水分利用方面的研 究等。由于作物的水分利用状况很难测定, 对不同 林农复合模式各组分如何利用和分配水资源尚不明 确, 一定程度上阻碍了生态恢复过程中最佳植物的 选择和配置(孙守家等, 2010)。因而, 了解林农复合 系统中的林木和作物间的种间水分关系至关重要 (Wanvestraut et al., 2004; Rezig et al., 2013)。

研究地下种间水分关系的一个难点是很难确定 植物的具体吸水位置和水源。植物根系的分布及根 深是决定植物水分利用来源的一个重要的因素。传 统的“根系挖掘法”能通过根系分布状况较为准确地 判断植物水分来源, 但是费时费力、且对农田的破 坏较大。在地下水位较浅或者山区有径流的区域,
挖根法也不能准确判断水源。此外, 尽管植物根系 常会贯穿整个土壤剖面, 但并不是所有的根都具有 吸收水分和养分的功能(Penna et al., 2013)。近年来, 氢氧稳定同位素以其较高的灵敏度与准确性为定量 研究植物水分来源和水分利用格局提供了新的技术 手段(徐庆等, 2009), 被广泛用于植物生态学研究 (Snyder \& Williams, 2000; Rose et al., 2003; 聂云鹏 等, 2011)。通过测定植物木质部水分和可能的水源 水中的氞同位素, 利用Isosource模型计算出的植物 水分来源能准确地获得某一时期植物的实际吸水区 域和水分来源(Ehleringer et al., 1991)。目前利用稳 定氢氧同位素技术对农林复合系统的水分利用方面 的研究相对较少(Sher et al., 2010; Sun et al., 2014)。 在本研究区济源市克井镇, 核桃种植面积占当地丘 陵山地果园面积的 $80 \%$ 以上, 其中核桃-药材复合系 统占 $20 \%$ 以上。本文采用稳定水同位素技术研究了 该区核桃-菘蓝/决明果药复合系统各组分的水分来 源和吸收比例, 试图明确该果药复合系统的种间竞 争和互利关系, 从而为当地林药配置模式的选择提 供理论依据。

\section{1 试验材料和方法}

\section{1 研究区域概况}

试验地点位于河南省济源市境内黄河小浪底森 林生态系统定位研究站 $\left(35.02^{\circ} \mathrm{N}, 112.47^{\circ} \mathrm{E}\right)$ 。该试 验区地处太行山南段南麓, 属暖温带大陆性季风气 候。全年日照时间为 $2367.7 \mathrm{~h}$, 年日照率为 $54 \%$, 多 
年平均 $\geqslant 0{ }^{\circ} \mathrm{C}$ 积温为 $5282{ }^{\circ} \mathrm{C}$ 。年降水量 $641.7 \mathrm{~mm}$, 主要集中在6-9月，占全年降水量的 $68.3 \%$ 。试验区 土壤以石灰岩风化母质淋溶性褐色土为主, 土层厚 度 50-80 cm, pH值7.6-8.5, 石砾含量 $10 \%-18 \%$, 速 效氮21.4-80.0 mg $\mathrm{kg}^{-1}$, 速效磷2.60-8.16 $\mathrm{mg} \cdot \mathrm{kg}^{-1}$, 速效钾 60-102.35 $\mathrm{mg} \cdot \mathrm{kg}^{-1}$, 有机质 $8.28-16.5$ $\mathrm{g} \cdot \mathrm{kg}^{-1}$ 。

\section{2 试验材料}

以水平梯田条件下的核桃-菘蓝(Isatis tincto$r i a)$ /决明(Senna tora)复合系统和单作系统为对象进 行为期 2 年的研究。梯田东西长约 $140 \mathrm{~m}$, 南北宽约 $25 \mathrm{~m}$ 。间作和单作系统核桃树种植于2006年, 树带 行向为东西向, 株行距为 $3 \mathrm{~m} \times 8 \mathrm{~m}$, 平均树高、地 径和冠幅分别为 $5.2 \mathrm{~m} 、 14.1 \mathrm{~cm}$ 和 $2.7 \mathrm{~m}$ 。菘蓝为秋 种夏初收获，决明为夏种秋收。于2011年11月15日 播种菘蓝，2012年6月8日收获; 当年7月3日换茬决 明、10月10日采收。2012年11月19日再播种菘蓝、 2013年6月 15 日收获; 当年6月 22 日换茬决明、10月 17 日采收。菘蓝和决明播种株行距均为 $20 \mathrm{~cm} \times 50$ $\mathrm{cm}$, 南北两侧各距离核桃树 $150 \mathrm{~cm}$ 。单作菘蓝/决明 位于复合系统西南侧约 $20 \mathrm{~m}$ 的梯田中。整个生育 期所有模式的土壤水分均来自雨水、无灌溉补水 措施。

\section{3 试验方法}

\subsection{1 土壤水分和气象因子测定}

于 2012 年和 2013 年, 采用时域反射仪 (TRIME-T3, IMKO, Ettlingen, Germany)测定土壤含 水量。分别在核桃-菘蓝/决明复合系统、单作核桃 和单作菘蓝/决明系统中提前埋设长度为 $80 \mathrm{~cm}$ 的时 域反射仪测量管，其中，间作核桃和单作核桃地中 的埋设位置在距离核桃树木北侧 $0.5 \mathrm{~m}$ (N0.5)、 $1.5 \mathrm{~m}$ $(\mathrm{N} 1.5) 、 4 \mathrm{~m}(\mathrm{M})$ 和南侧 $1.5 \mathrm{~m}(\mathrm{~S} 1.5)$ 处, 单作药草地 中随机埋设, 每个位置各设置3次重复。每次采样时 用时域反射仪测定垂直方向上0-20、20-40、40-60 和 $60-80 \mathrm{~cm}$ 处的土壤含水量。

在距离试验地北侧 $10 \mathrm{~m}$ 处设立小气候自动观 测系统, 连续观测空气温度 $\left(T_{\mathrm{a}}\right)$ 、相对湿度 $(R H)$ 和降 水量 $(R F)$, 所采用的温湿度传感器为 HMP45C (Vaisala, Vantaa, Finland)、雨量筒传感器为TE525M (Campbell Scientific, Logan, USA), 数据采集器均为 CR10X (Campbell Scientific, Logan, USA)。设定每2 $\min$ 采集 1 次, 每 $10 \mathrm{~min}$ 输出 1 组平均值。

\subsection{2 植物和土壤水分取样和测定}

在各个取样时期分别选取 3 棵核桃树剪取一年 生枝条，迅速剥去树皮、装入采样瓶。同时在这3株 核桃周围分别进行土壤和植物取样, 其中分别在 $\mathrm{N} 1.5 、 \mathrm{~N} 2.5$ (核桃树北侧 $2.5 \mathrm{~m}$ ) 、M、S2.5 (核桃树南 侧 $2.5 \mathrm{~m}$ )、S1.5位置处对土壤和菘蓝/决明主茎取样。 土壤取样参照Snyder和Williams (2000)的方法分浅 层 $(0-30 \mathrm{~cm})$ 和深层 $(30-100 \mathrm{~cm})$ 进行, 浅层分别取 0-10、10-20和 $20-30 \mathrm{~cm}$ 土壤, 深层将 $30-80 \mathrm{~cm}$ 的土 壤混匀。所有土壤和植物样品装入采样瓶后都立即 用Parafilm封口膜密封，以防止水分蒸发分馏，储藏 在0 $-5{ }^{\circ} \mathrm{C}$ 便携式冷藏包内, 带回实验室后冷冻 $(-20$ $\left.{ }^{\circ} \mathrm{C}\right)$ 保存。

雨水样品：收集研究区2012和2013年生长季单 次雨量超过 $5 \mathrm{~mm}$ 的降雨, 密封冷藏 $\left(5^{\circ} \mathrm{C}\right)$ 保存。

用水分真空抽提系统(LI-2000, Los Gatos Research, Mountain View, USA)对土壤和植物木质部 的水分进行抽提，然后用液态水同位素分析仪 (DLT-100, Los Gatos Research, Mountain View, USA) 测定液态水样品氞同位素比值。由于重同位素的自 然丰度很低, 所以一般测定重、轻同位素的相对丰 度或同位素比率，国际上统一采用同位素比值 $(\delta$ 值) 表示, $\delta \mathrm{D}$ 为样品中気和氢两种同位素比值相对于标 准物质 (Vienna Standard Mean Ocean Water, V-SMOW)对应比值的相对千分率(\%), 因而自然丰 度中一般植物和土壤水 $\delta \mathrm{D}$ 值为负值, 且 $\delta \mathrm{D}$ 值越大 (偏正)表明重同位素所占的比率越高, 在植物和土 壤水分蒸腾和蒸发中一般氢同位素会先分馏出去、 留下重同位素氝, 因而蒸发越严重的水样 $\delta \mathrm{D}$ 值越 高。分析方程为:

$$
\delta \mathrm{D}=\left(R_{\text {sample }} / R_{\text {standard }}-1\right) \times 1000
$$

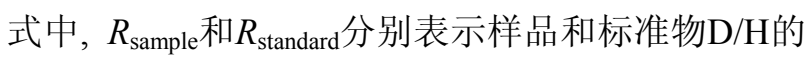
摩尔比率, 精度为 $\pm 0.2 \%$ 。

由于研究地土层较薄(仅 50-80 $\mathrm{cm}$ ), 薄土层下 即为石灰岩母质层, 复合系统各组分无法吸收到地 下水、水分来源仅为雨水补充的土壤水, 所以将不 同层次的土壤水作为其几个可能的水分来源。根据 Phillips和Gregg (2003)提出的确定各端元贡献比例 上、下限的多源质量守恒的IsoSource方法，计算核 桃、菘蓝和决明分别对各个取样土层的水分吸收比 例。在计算过程中设定两个参数：资源增量参数 $(2 \%)$ 和质量平衡忍受参数 $(0.05)$ 。 


\section{2 结果和分析}

\section{1 研究地气象因子及土壤含水量的季节变化}

\subsection{1 研究地气象因子的季节变化}

研究区温湿度和降水量如图1所示。2012和 2013年生长季(4-10月)的平均温度、湿度和总降水 量分别为 22.18 和 $22.41{ }^{\circ} \mathrm{C} 、 64.86 \%$ 和 $70.64 \% 、 493.0$ 和409.0 mm, 降水多集中在7-8月, 且2012年降水 量比2013年多。2013年菘蓝收获期(5月末至6月初) 降水较多。在2012和2013年菘蓝生长时期的气温、 湿度和降水量分别为 22.45 和 $19.97{ }^{\circ} \mathrm{C} 、 42.84 \%$ 和 $57.91 \% 、 64.9$ 和 $137.5 \mathrm{~mm}, 2012$ 年春季比2013年同一 时期干旱、气温高。在2012和2013年决明生长时期 的气温、湿度和降水量分别为 23.06 和 $24.25{ }^{\circ} \mathrm{C}$ 、 $78.65 \%$ 和 $80.85 \% 、 325.0$ 和 $268.4 \mathrm{~mm}$ ，即 2012 年雨季 比2013年雨季降水多。总的来说菘蓝生长时期处于 春天干旱少雨期, 而决明生长前中期处于雨季、生 长后期处于秋旱期。

\subsection{2 复合系统和单作系统土壤含水量的季节变化}

图2所示为同一时期不同土层土壤含水量的平 均值的季节变化, 受降水影响, 各系统2012年的土 壤水分总体高于2013年(雨水较多的2013年菘蓝生 长末期除外)。2012年, 随着菘蓝的生长, 核桃-菘蓝 间作、单作核桃和单作菘蓝各个系统中的土壤含水 量均呈现逐渐减少的趋势。3 月28日各系统的土壤平 均含水量为 $18.91 \%$, 此时树木尚未长叶, 气温较 低、太阳辐射也相对较低(3月平均光合有效辐射不 足 $150 \mu \mathrm{mol} \cdot \mathrm{m}^{-2} \cdot \mathrm{s}^{-1}$, 明显小于 $4-8$ 月的值), 以微弱 的土壤蒸发为主，土壤水分处于相对稳定状态; 4月 25 日土壤平均含水量明显降低(14.86\%), 此时期气 温上升快, 植物根系开始萌动、吸水, 并随着叶生物 量的增长蒸腾量迅速上升, 致使土壤水分被大量消 耗; 到6月份温度达到最高, 而降雨还未来临, 土壤 含水量降到最低, 仅9.96\%。2013年菘蓝生长前期土 壤较为干旱(含水量仅 $10 \%$ 左右), 而受到前一周降 雨补充, 菘蓝生长后期(5月29日)土壤含水量明显提
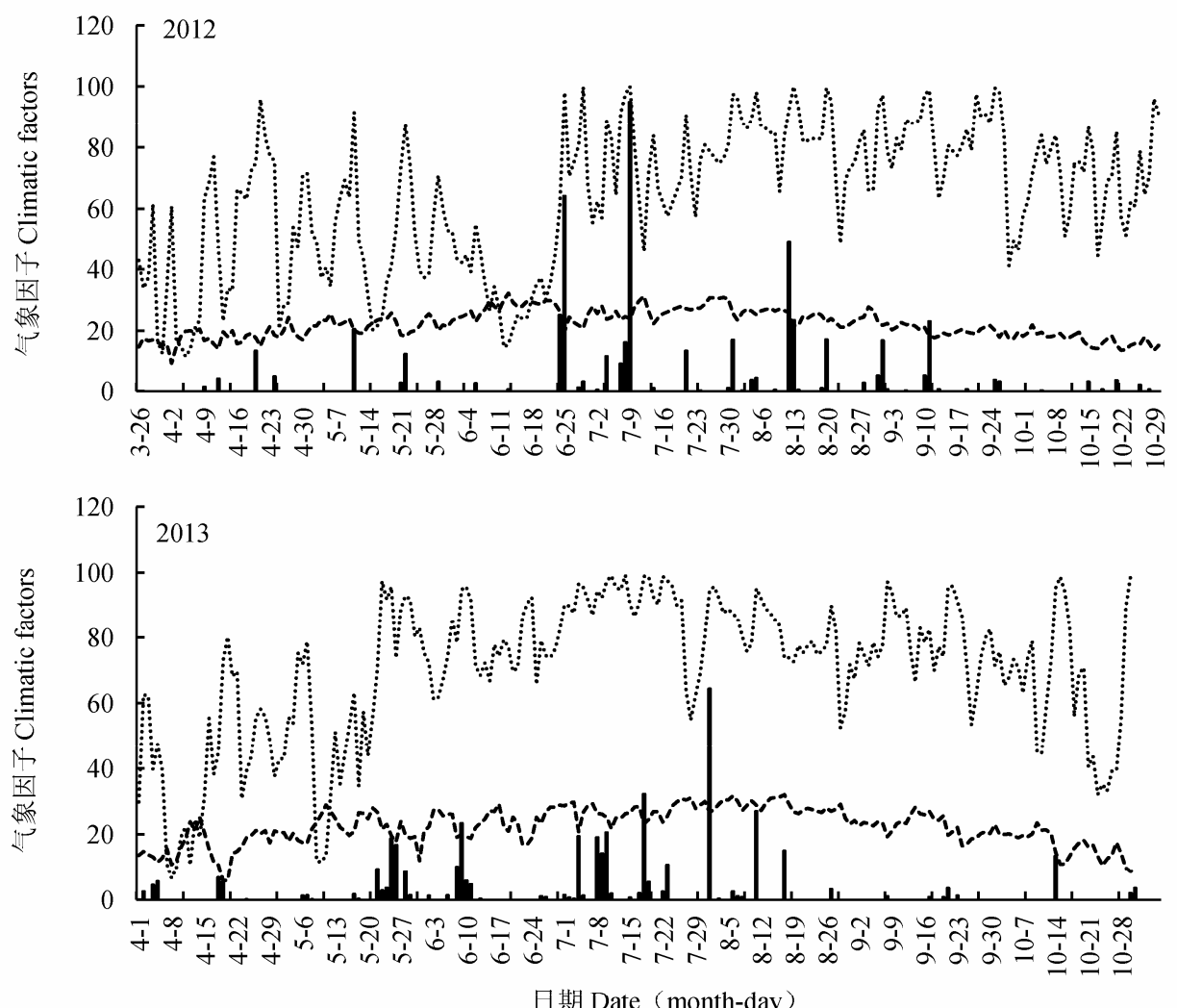

日期 Date (month-day)

降水量 Rainfall (mm) 气温 Air temperature $\left({ }^{\circ} \mathrm{C}\right)$ 相对湿度 Relative humidity (\%)

图1 研究区2012和2013年生长季的气象因子。

Fig. 1 Dynamics of climatic variables during the growth period in 2012 and 2013 in the study area. 

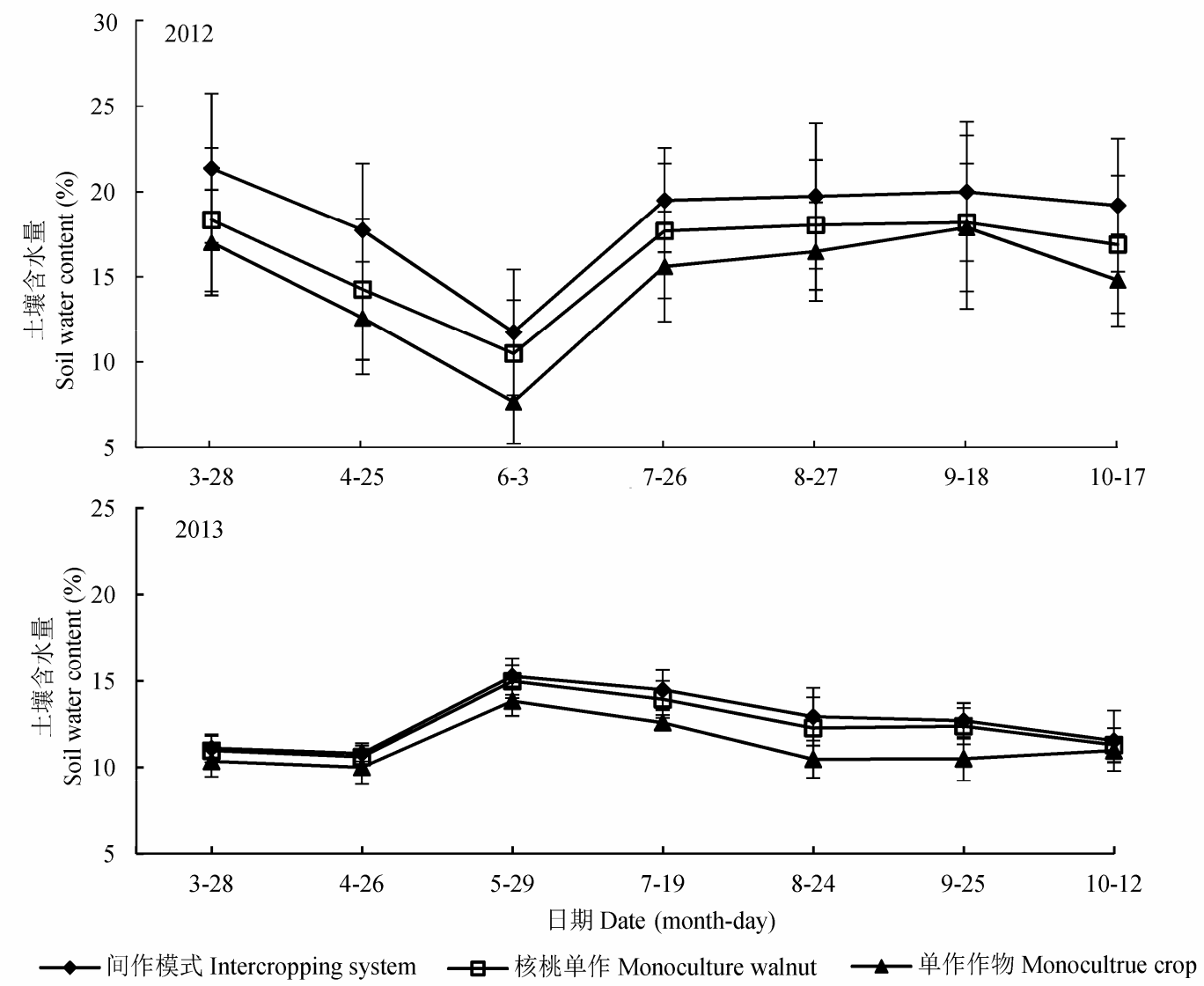

图2 2012和2013年不同系统土壤含水量的时间动态变化(平均值土标准偏差)。

Fig. 2 Temporal variations of soil water content in different intercropping systems in 2012 and 2013 (mean $\pm S D$ ).

高(达14.70\%)。

在2012年决明生长时期, 各系统在不同阶段土 壤含水量的差异并不显著。从6月底雨季来临至9月 底, 虽然这一阶段气温很高, 树木也处于旺盛生长 时期, 植物蒸滕和土壤蒸发作用很强, 但由于较多 雨水的入渗补充了土壤水分的耗损量, 土壤水分开 始逐渐积蓄, 并以恢复过程占主导地位。10月中旬, 随着雨水量的减少, 各系统的土壤含水量随之下 降。2013年决明生长时期, 由于相对雨水较少, 各系 统的土壤含水量则随着决明的生长出现缓慢减少的 趋势。

在相同时期的土壤含水量表现为: 果药复合系 统的最高、单作果树的次之, 而单作菘蓝和单作决 明的则最低, 其中在 2012 年6月3日、7月27日和 10 月 17日3者间差异显著 $(p<0.05)$ (图2)。在较为干旱的 2013年, 果药复合系统和单作果树地块的土壤含水 量则差异较少，但复合系统在 3 月 28 日、8月24日和 9 月 25 日仍然显著高于单作菘蓝/决明地块的土壤含 水量 $(p<0.05)$ 。林药复合系统的土壤水分在 2012 年、
2013 年上半年平均比单作菘蓝增加了 $26.74 \%$ 和 $7.93 \%$, 在下半年平均比单作决明增加了 $17.39 \%$ 和 $13.65 \%$ 。

土壤含水量的垂直分布特征如图3所示，0-10 $\mathrm{cm}$ 表层土壤受到温度、辐射、降水等气象因子和土 壤蒸发等的影响最大, 使得表层土壤水分差异较 大。随着土壤深度的增加, 各个系统土壤含水量整 体上呈现增加的趋势, 但在 40-60 $\mathrm{cm}$ 的土层中各系 统的土壤含水量均有一定程度的减少。垂直方向上 的土壤含水量表现为: 单作菘蓝和单作决明在各个 土层均明显低于核桃-菘蓝复合系统和核桃-决明复 合系统，而单作核桃和间作核桃则差异并不大。在 2012年, 单作和间作菘蓝的土壤含水量在各个土层 均分别小于单作和间作决明 $(p<0.01)$, 而2013年该 差异不明显 $(p>0.1)$ 。

图4所示两种果药复合系统中, 均为位于核桃 树行中间位置 $(\mathrm{M})$ 的土壤含水量最低, 其次为核桃 树行南侧, 距离核桃树行北侧的土壤含水量最高, 尤其是核桃树下。与不同系统间土壤含水量差异性 

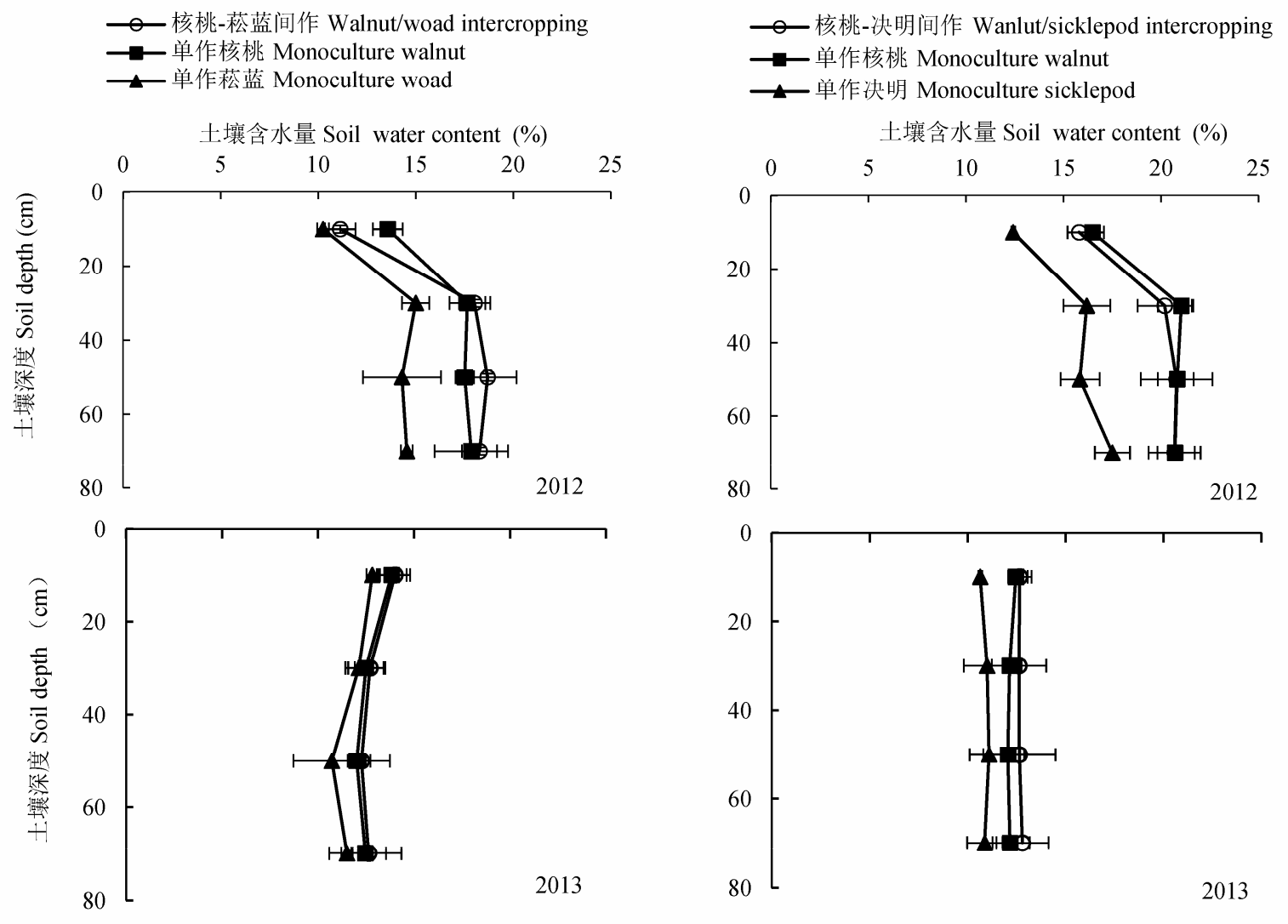

图3 2012和2013年不同系统土壤含水量的垂直变化特征(平均值土标准偏差)。

Fig. 3 Vertical variations of soil water content in different intercropping systems in 2012 and 2013 (mean $\pm S D$ ).

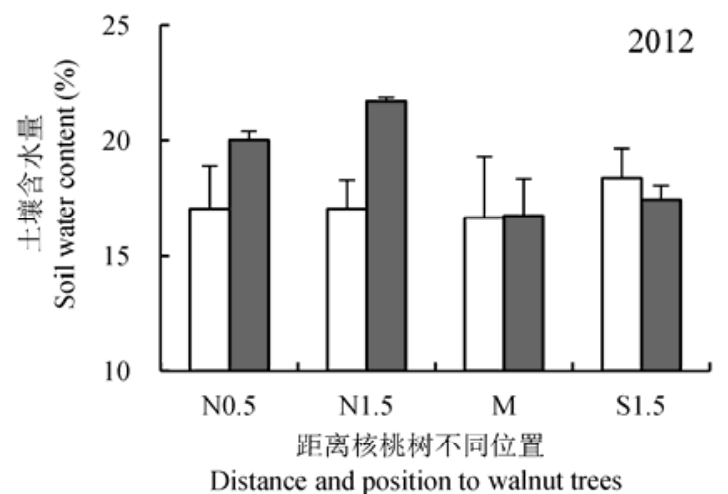

核桃/菘蓝间作 Walnut/woad intercropping

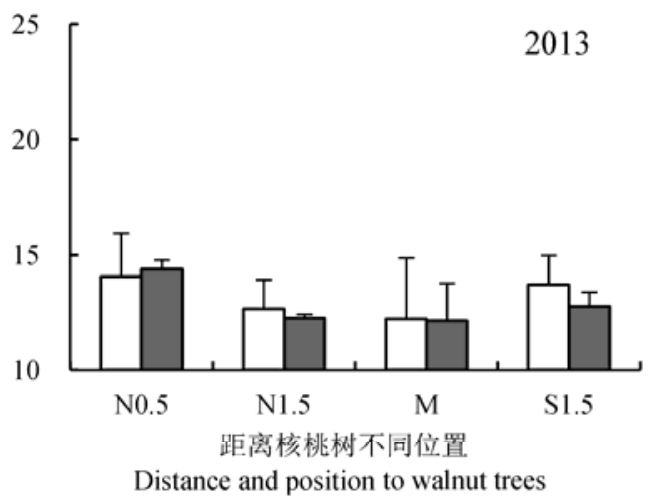

口核桃/决明间作 Wanlnut/sicklepod intercropping

图4 2012和2013年不同系统土壤含水量的水平变化特征(平均值土标准偏差)。N0.5、N1.5、M、S1.5分别为核桃树北侧 0.5 m、 $1.5 \mathrm{~m} 、 4 \mathrm{~m}$ 和南侧 $1.5 \mathrm{~m}$ 。

Fig. 4 Horizontal variations of soil water content in different intercropping systems in 2012 and 2013 (mean $\pm S D$ ). N0.5, N1.5, M, S1.5 denote distances of $0.5 \mathrm{~m}, 1.5 \mathrm{~m}, 4 \mathrm{~m}$ to north side and $1.5 \mathrm{~m}$ to south side of tree rows, respectively.

一致，距离树行不同位置的土壤含水量也表现为在 2012年6月3日、7月27日、10月17日和2013年3月28 日、8月24日和9月25日差异显著 $(p<0.05)$ 。上述结 果应该是由于树行两侧树冠遮阴减少了土壤水分的 蒸发。
2.2 不同复合系统各组分的 $\delta \mathrm{D}$ 值差异及雨水 $\delta \mathrm{D}$ 值 的季节变化

\subsection{1 雨水 $\delta \mathrm{D}$ 值的变化}

由图 5 可以看出, 2012和2013年生长季降水的 $\delta \mathrm{D}$ 值波动幅度较大，这两年均表现为降水较多的 


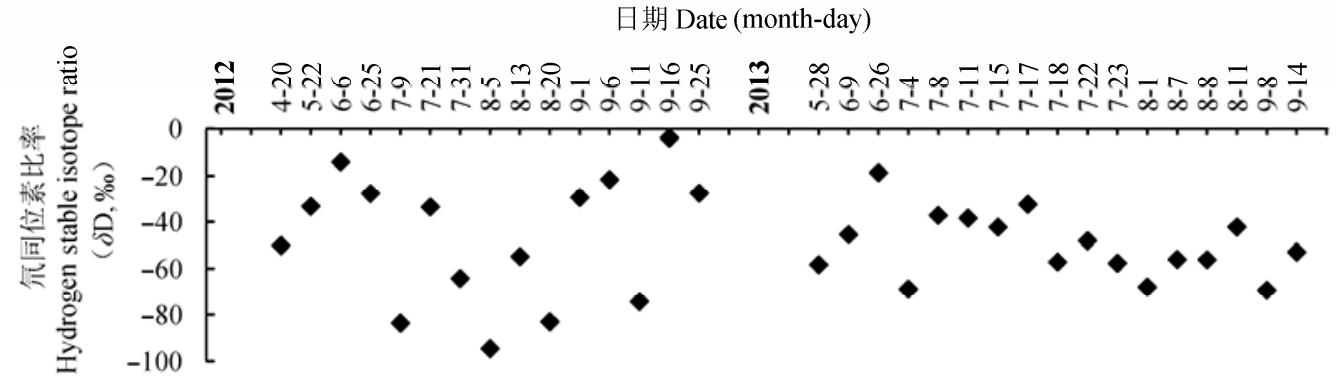

图5 研究区域2012年和2013年雨水 $\delta \mathrm{D}$ 值。

Fig. 5 The $\delta \mathrm{D}$ value of rainwater in the study area in 2012 and 2013.

7-8月份 $\delta \mathrm{D}$ 偏负，而4-6月和9月份 $\delta \mathrm{D}$ 值偏正。

对研究区的降水量和雨水 $\delta \mathrm{D}$ 值的相关分析结 果(图6)表明, 两者呈线性负相关关系 $(p<0.1)$ 。即降 水量越大, 雨水 $\delta \mathrm{D}$ 值越偏负。

降水量 Rainfall (mm) $\begin{array}{lllllllllll}0 & 10 & 20 & 30 & 40 & 50 & 60 & 70 & 80 & 90 & 100\end{array}$

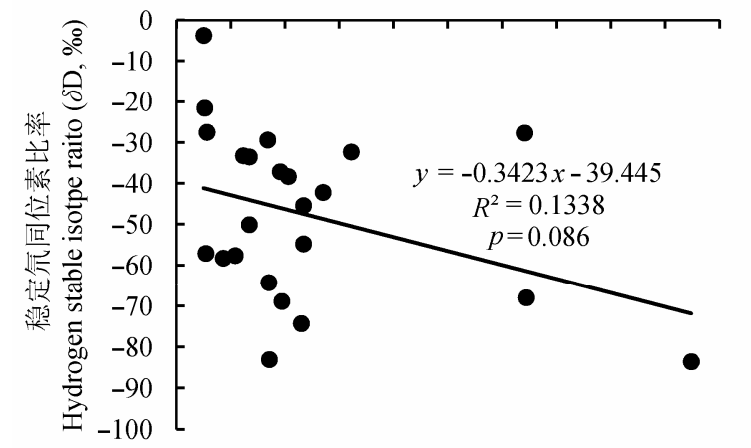

图6 研究区降水量和雨水 $\delta \mathrm{D}$ 值的相关关系。

Fig. 6 The relationship between rainfall and $\delta \mathrm{D}$ value of rainwater in the study area during 2012-2013.

\subsection{2 土壤水 $\delta \mathrm{D}$ 值变化特征}

2.2.2.1 垂直方向土壤水 $\delta \mathrm{D}$ 值的变化 研究区域 降水 $\delta \mathrm{D}$ 值的差异造成不同时期土壤水的 $\delta \mathrm{D}$ 值变化。 图7和图8可见，核桃-菘蓝间作系统和单作菘蓝土 壤水 $\delta \mathrm{D}$ 值在不同时期大都随着土壤深度的增加而 减小(除了在5月30日, 受取样前两日降雨的影响, 土壤表层水分 $\delta \mathrm{D}$ 值明显偏负)。方差分析和多重比 较结果显示, 在间作系统内, 不同土层土壤水 $\delta \mathrm{D}$ 值 在2012年4月26日、6月3日、2013年3月24日、4月26 日、 5 月 30 日和 9 月 25 日均差异显著 (分别为 $p<$ $0.0001 、 0.001 、 0.01 、 0.01 、 0.0001$ 和 0.0001$)$; 在 单作作物地块, 不同土层土壤水 $\delta \mathrm{D}$ 值在 2012 年 4 月
26日、2013年4月26日、5月30日和9月25日也均差异 显著(分别为 $p<0.0001 、 0.001 、 0.0001$ 和 0.0001 )。 决明生长前期和中期(7-9月), 受降水影响, 浅层土 壤水 $\delta \mathrm{D}$ 值变化较大, 间作和单作决明系统中土壤水 $\delta \mathrm{D}$ 值均随着土层深度的增加逐渐增大; 而决明生长 后期, 降雨减少, 随着土层深度的增加土壤水 $\delta \mathrm{D}$ 值 略有减少。在各个土层中, 单作系统土壤水 $\delta \mathrm{D}$ 值均 比间作系统的偏正。

2.2.2.2 水平方向土壤水 $\delta \mathrm{D}$ 值的变化 图9所示, 核桃-菘蓝复合系统中距离核桃不同位置土壤水的 $\delta \mathrm{D}$ 值差异较小, 在2012年和 2013 年均表现 $\mathrm{N} 2.5$ 处最 高, 其次是 $\mathrm{M}$ 和 $\mathrm{S} 2.5$ 处, N1.5 和 $\mathrm{S} 1.5$ 处的最小, 但不 同位置间差异不显著(在2012和 2013 年分别为 $p=$ 0.249和0.577)。核桃-决明复合系统中距离核桃不同 位置土壤水的 $\delta \mathrm{D}$ 值在 2012 和 2013 年均呈现为距离 树行两边低中间高的现象，并且在2012年树行中间 位置显著高于树行两侧 $(p<0.001), 2013$ 年则差异不 显著。

2.2.2.3 不同复合系统各组分木质部水 $\delta \mathrm{D}$ 值差异 木质部水 $\delta \mathrm{D}$ 值主要受到所吸收的土壤水 $\delta \mathrm{D}$ 值的影 响。由于单作系统土壤水 $\delta \mathrm{D}$ 值均比间作系统的偏正, 因而图10显示, 在菘蓝生长时期, 各组分木质部水 的 $\delta \mathrm{D}$ 值表现为间作核桃最小、间作菘蓝居中、单作 菘蓝最偏正，且在2012年4月26日以及 2013 年3月 24 日和4月26日差异显著 $(p<0.05)$ 。而在雨水较多的 2013年5月30日各组分 $\delta \mathrm{D}$ 值几乎无差异。在菘蓝生 长前中期, 复合系统中核桃和菘蓝茎内水分 $\delta \mathrm{D}$ 值变 化不大，均在-40\%o左右。但由于持续干旱，在 2012 年菘蓝生长后期(6月 3 日)各组分 $\delta \mathrm{D}$ 值明显偏正，特 别是单作菘蓝; 而在2013年5月30日由于受连续降 雨影响则各组分 $\delta \mathrm{D}$ 值均偏负 $(-60 \% 0$ 左右 $)$ 。受降雨影 


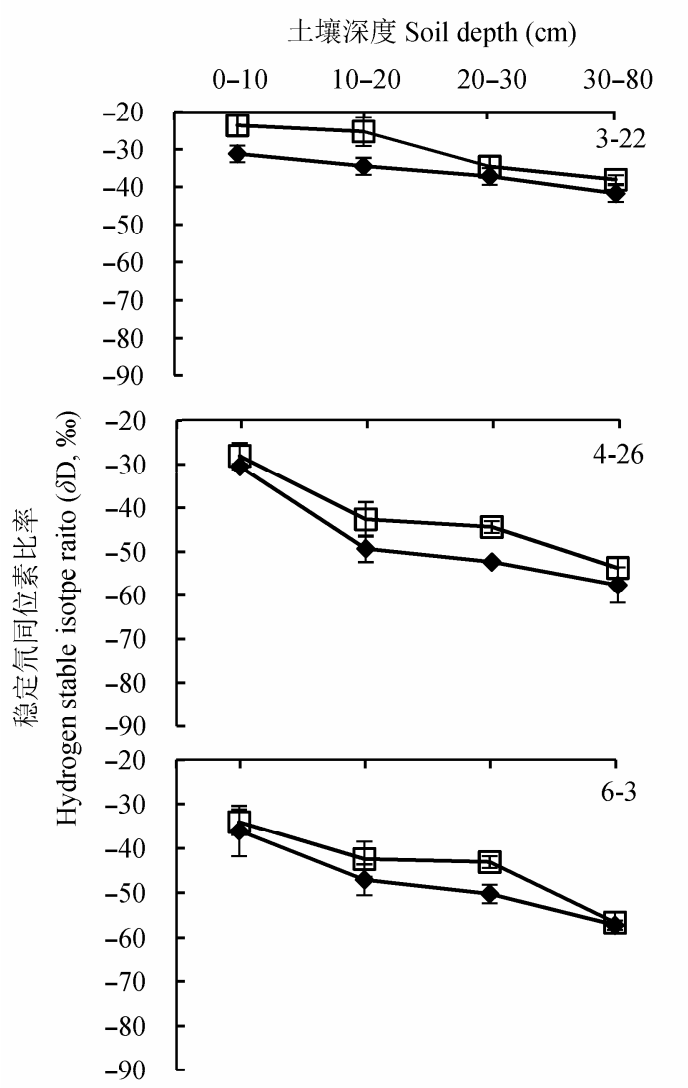

-核桃/菘蓝间作系统 Walnut/woad intercropping system 口 单作菘蓝系统 Monoculture woad

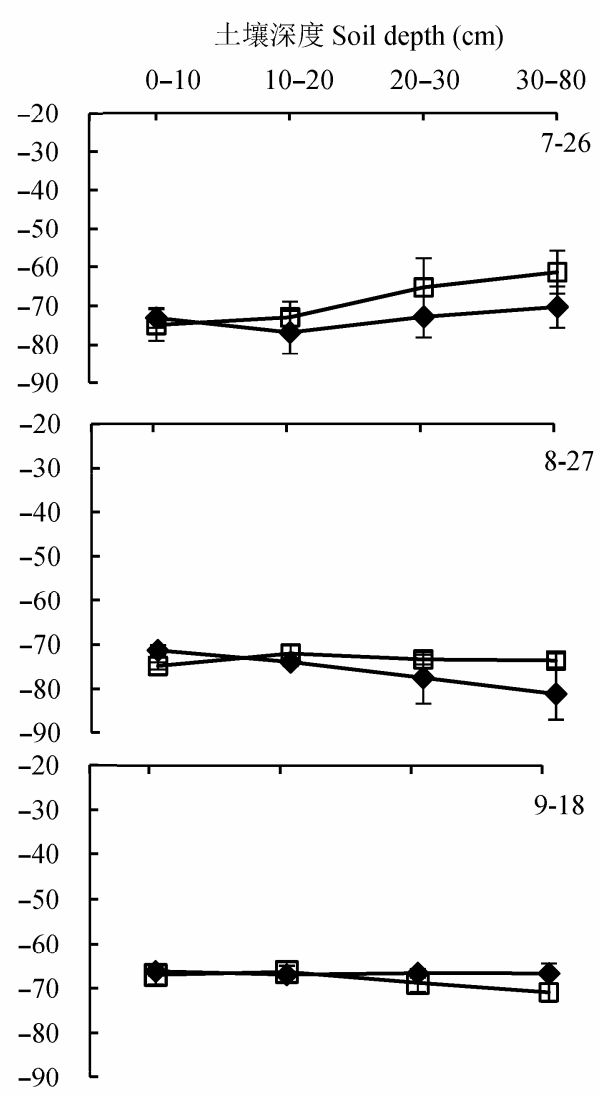

核桃/决明间作系统 Wanlnut/sicklepod intercropping system 口单作决明系统 Monoculture sicklepod

图7 2012年不同复合系统不同土层 $\delta \mathrm{D}$ 值的差异(平均值土标准偏差)。

Fig. 7 Differences in $\delta$ D value of soil water for different soil layers between different intercropping systems in 2012 (mean $\pm S D$ ).

响, 核桃和决明木质部水分 $\delta \mathrm{D}$ 值在 2012 年变化较复 杂; 在2013年3次取样均表现为间作核桃最小、间作 决明居中、单作决明则最偏正(其中在7月 18 日和 8 月24日差异显著, $p<0.05$ )。

\section{3 不同系统水分来源比例}

\subsection{1 核桃-菘蓝复合系统水分来源比例}

由图11可知, 2012年核桃-菘蓝间作系统中核桃 主要利用深层 $(30-80 \mathrm{~cm})$ 土壤水, 在苗期(3月22 日)、开花期(4月26日)和成熟期(6月3日)比例分别为 $51.8 \%$ 、60.4\%和 $66.9 \%$ 。间作菘蓝和单作菘蓝主要 利用浅层 $(0-30 \mathrm{~cm})$ 土壤水, 生长期平均值分别为 $87.3 \%$ 和 $85.9 \%$ 。间作和单作菘蓝在开花期和成熟期 水源差异较小, 其中间作菘蓝对深层土壤水的吸收 比例分别为 $6.7 \%$ 和 $25.8 \%$, 单作菘蓝则分别为 $11 \%$ 和 $31.4 \%$ 。干旱以及缺少核桃树的遮阴保水作用, 造 成单作菘蓝的土壤(特别是浅层土)水分消耗多、氛 同位素分馏严重，因而吸收的深层土壤水稍多。

在2012年菘蓝生长苗期, 单作菘蓝体内水分完
全来源于浅层土壤，但间作菘蓝体内却有 $5.7 \%$ 的水 分来自于深层土壤。在2013年苗期也出现了同样的 情况, 间作菘蓝对深层土壤水的利用比例更是上升 到 $9.7 \%$ (图12)。

图12所示，在2013年菘蓝生长中期的水源与 2012年的较为一致。受取样前降雨的影响, 2013年5 月 30 日菘蓝茎和核桃木质部水 $\delta \mathrm{D}$ 值接近雨水的，而 与土壤水中的氞同位素信息不一致，因而未计算各 土层土壤水分来源比例。2013年核桃-菘蓝间作系统 中核桃利用浅层和深层土壤水的比率相当, 其中在 苗期(3月24日)和开花期(4月26日)对深层土壤水的 利用比例分别为 $45.4 \%$ 和 $53.7 \%$ 。间作菘蓝和单作菘 蓝主要利用浅层土壤水, 生长期平均分别为 $88.2 \%$ 和 $92.7 \%$ 。

\subsection{2 核桃-决明系统水分来源比例}

图13显示, 2012年核桃-决明间作系统中核桃主 要利用0-30 cm浅层土壤水分, 在苗期(7月26日)、开 花期(8月27日)和成熟期(9月18日)比例分别为 


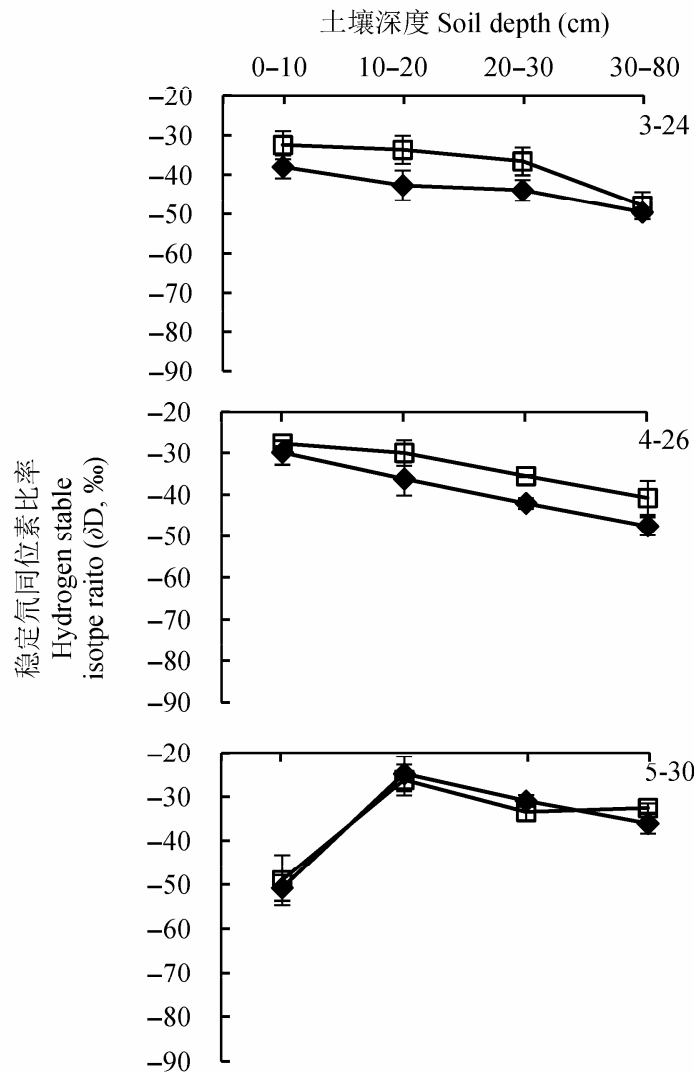

核桃/菘蓝间作系统 Walnut/woad intercropping system 口单作菘蓝系统 Monoculture woad

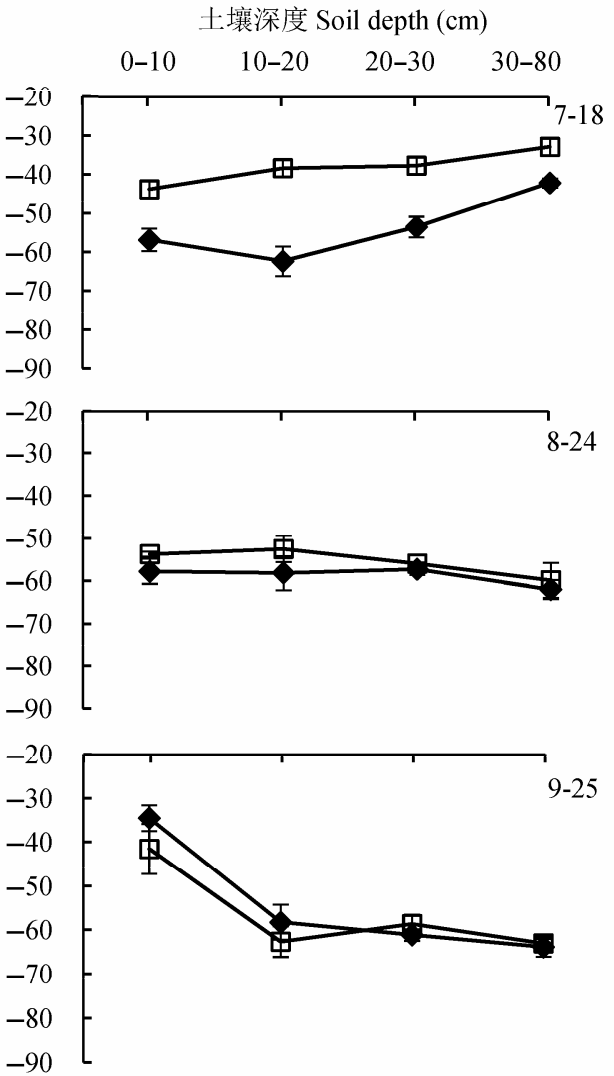

核桃/决明间作系统 Wanlnut/sicklepod intercropping system 单作决明系统 Monoculture sicklepod

图8 2013年不同复合系统不同土层 $\delta \mathrm{D}$ 值差异(平均值土标准偏差)。

Fig. 8 Differences in $\delta$ D value of soil water for different soil layers between different intercropping systems in 2013 (mean $\pm S D$ ).

$76.1 \%$ 、73.2\%和 $60.5 \%$ 。间作决明和单作决明也主 要利用浅层土壤 $(0-30 \mathrm{~cm})$ 中的水分, 生长季平均值 分别为 $92.2 \%$ 和 $86.8 \%$ 。在苗期, 间作和单作决明体 内水分则完全来自于浅层土壤; 在开花期, 两者则 有一小部分来源于深层土壤, 分别为 $8.3 \%$ 和 $15.1 \%$; 到成熟期, 两者对深层水的利用比例则分别增加到 $15.0 \%$ 和 $24.6 \%$ 。

2013年 8 月 24 日核桃和决明茎内的水分 $\delta \mathrm{D}$ 值接 近取样前降水, 而非土壤水。在2013年决明生长前 期和后期，核桃和决明水分来源比例同2012类似， 其中间作核桃也主要利用0-30 $\mathrm{cm}$ 浅层土壤水分, 在苗期(7月18日)和成熟期(9月25日)比例分别为 $96.3 \%$ 和 $64.0 \%$ 。间作决明和单作决明在整个生长季 平均 $89.8 \%$ 和 $87.7 \%$ 的水分也主要来自浅层土壤(图 14)。在苗期，间作和单作决明均未利用深层土壤 水。在决明成熟期，由于土壤含水量减少，不同复合 系统各组分对深层土壤水的利用比例均有增加。

\section{4 土壤水 $\delta \mathrm{D}$ 值和土壤含水量的关系}

分别对2012年和2013年菘蓝和决明生长时期的 土壤水 $\delta \mathrm{D}$ 值与土壤水分含量做相关分析(图15), 在 2012年和2013年的菘蓝生长时期，两者呈显著负相 关关系(分别为 $p<0.1$ 和 $p<0.05$ ); 在决明生长时期 则呈正相关关系，但相关性均不显著 $(p>0.1)$ 。整个 生长季则表现为两者在 2012 年呈负相关关系 $(p<$ $0.001) 、$ 在2013年呈正相关关系 $(p<0.05)$ 。

\section{3 结论和讨论}

由于 2013 年生长季降雨比2012年少 $84 \mathrm{~mm}$, 造 成2013年总体较为干旱, 尤其是在菘蓝生长前期 (土壤含水量仅 $10 \%$ 左右)和决明生长后期。果药复合 系统的土壤水分2012年和2013年相比单作菘蓝和单 作决明均提高了 $8 \%$ 以上，表明林药复合系统中核 桃树的遮阴和对小气候的改善等降低了土壤水分 的蒸发，有效地保持了复合系统内的土壤水分。 


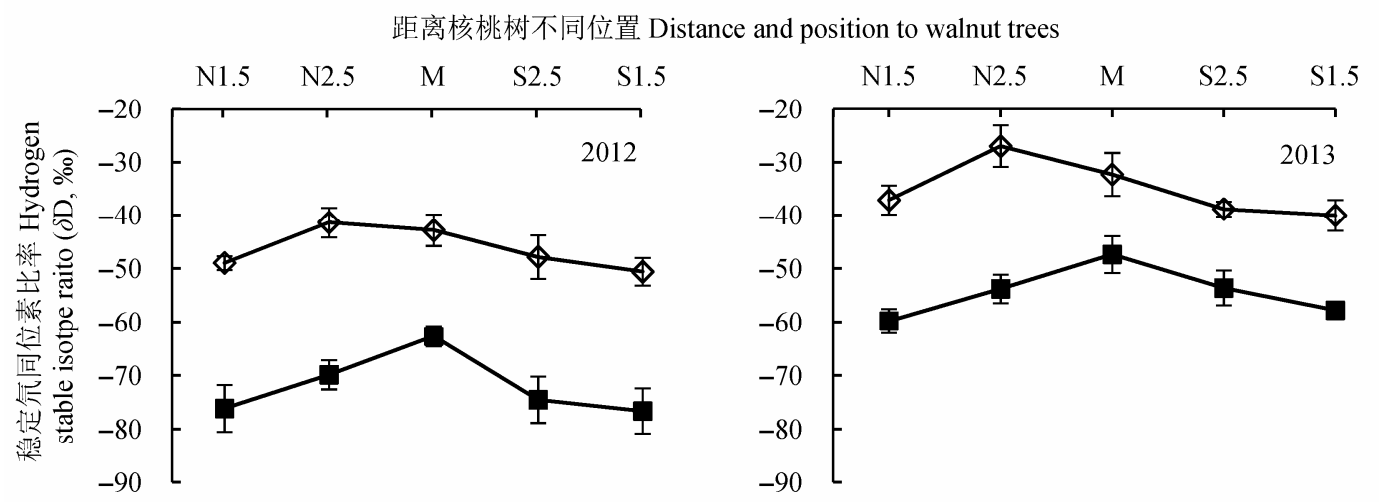

$\diamond$ 核桃/菘蓝间作系统 Walnut/woad intercropping system 一核桃/决明间作系统 Wanlnut/sicklepod intercropping system

图92012和2013年复合系统内距离树行不同位置土壤水 $\delta \mathrm{D}$ 值的差异(平均值土标准偏差)。N1.5、N2.5、M、S2.5、S1.5分别 为核桃树北侧 $1.5 、 2.5 、 4 \mathrm{~m}$ 和南侧 $2.5 、 1.5 \mathrm{~m}$ 。

Fig. 9 Differences in $\delta \mathrm{D}$ value of soil water at different distances to tree row in intercropping systems in 2012 and 2013 (mean \pm $S D$ ). N1.5, N2.5, M, S2.5, S1.5 denote distances of $1.5 \mathrm{~m}, 2.5 \mathrm{~m}, 4 \mathrm{~m}$ to north side and $2.5 \mathrm{~m}, 1.5 \mathrm{~m}$ to south side of tree rows, respectively.
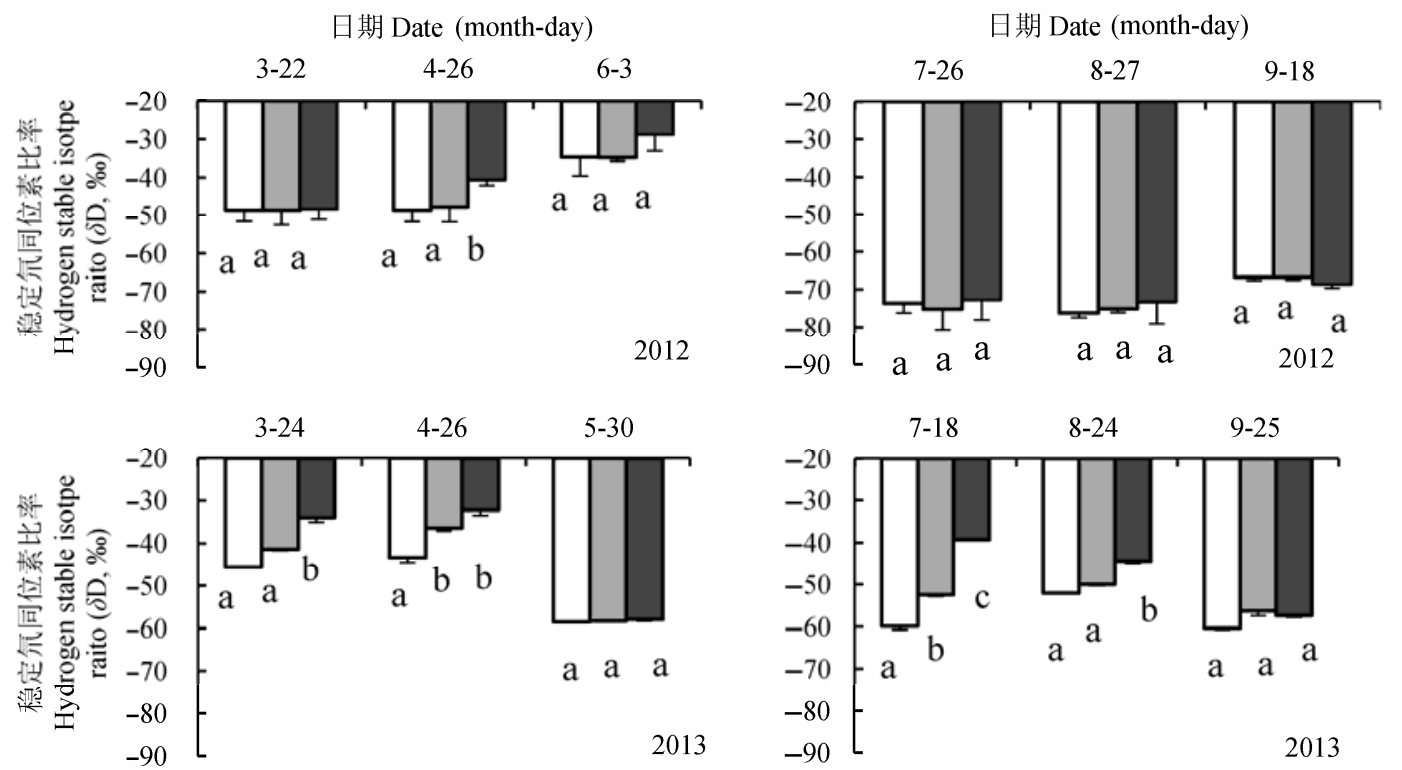

$$
\begin{aligned}
& \text { 口间作核桃 Intercropped walnut } \\
& \text { 口间作菘监 Intercropped woad } \\
& \text { 口单作菘监 Monoculture woad }
\end{aligned}
$$

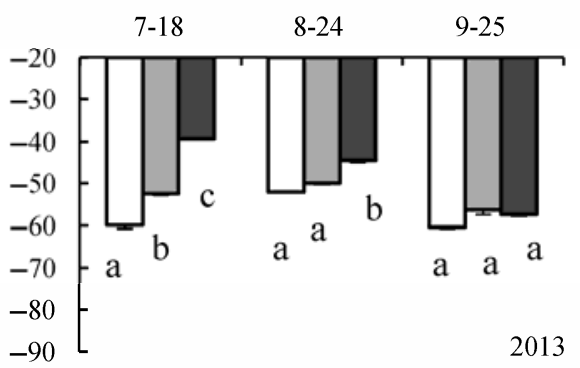

$$
\begin{aligned}
& \text { 口间作核桃 Intercropped walnut } \\
& \text { 口间作决明 Intercropped sicklepod } \\
& \text { 口单作决明 Monoculture sicklepod }
\end{aligned}
$$

图10 2012和2013年不同复合系统植物 $\delta \mathrm{D}$ 值(平均值沶准偏差)。不同小写字母表示不同复合模式差异显著 $(p<0.05)$ 。

Fig. 10 Stem $\delta$ D of plants from different intercropping systems in 2012 and 2013 (mean $\pm S D$ ). Different small letters indicate significant differences between different intercropping systems $(p<0.05)$.

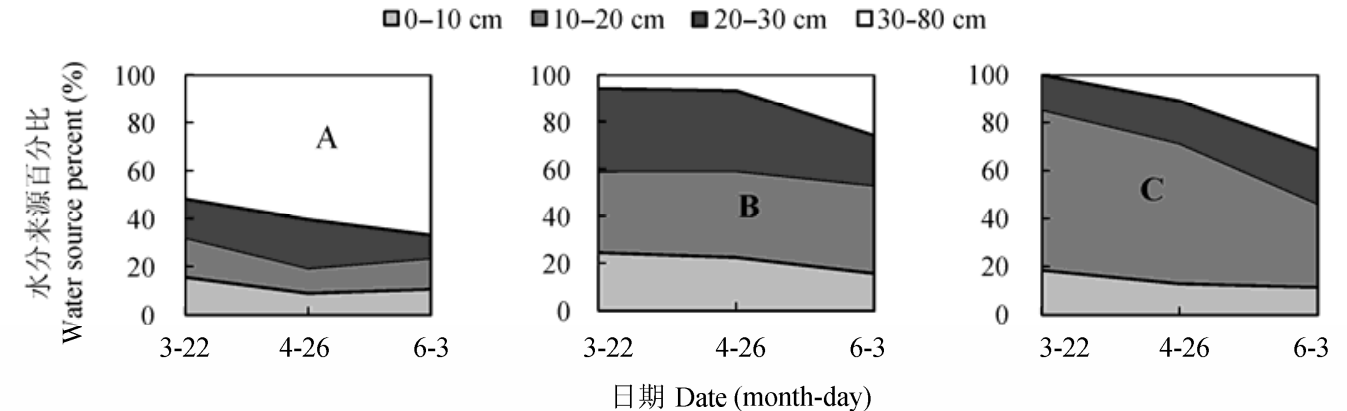

图112012年间作核桃(A)、间作菘蓝(B)和单作菘蓝(C)水分利用来源比例。

Fig. 11 Proportion of water sources for intercropped walnut (A), intercropped woad (B), and monocultural woad (C) in 2012. 


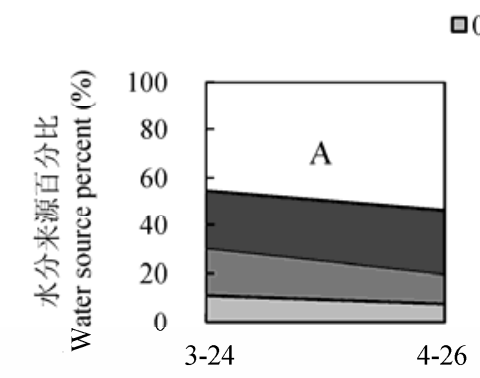

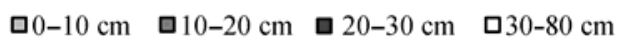
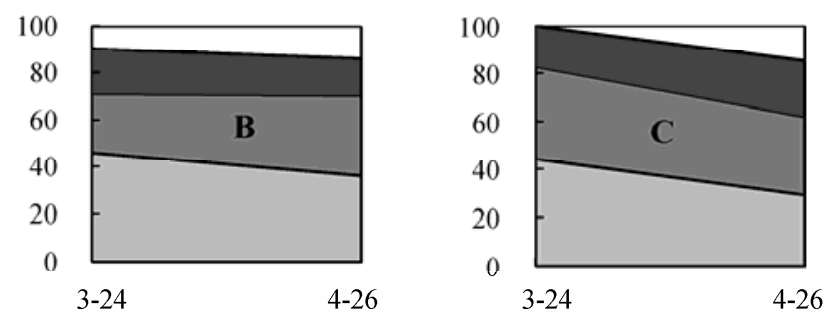

日期 Date (month-day)

图12 2013年间作核桃(A)、间作菘蓝(B)和单作菘蓝(C)水分利用来源比例。

Fig. 12 Proportion of water sources for intercropped walnut (A), intercropped woad (B), and monocultural woad (C) in 2013.

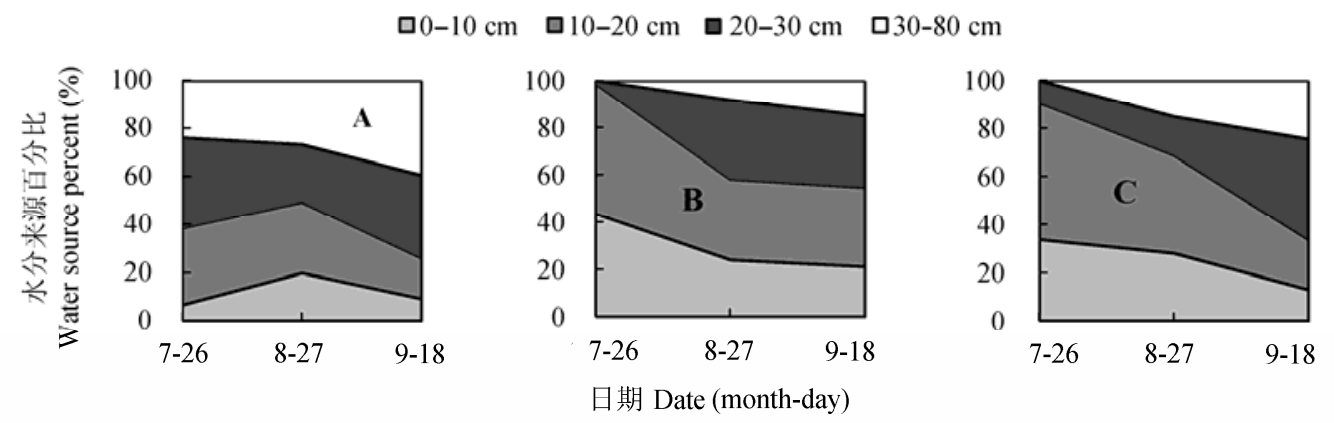

图13 2012年间作核桃(A)、间作决明(B)和单作决明(C)水分利用来源比例。

Fig. 13 Proportion of water sources for intercropped walnut (A), intercropped sicklepod (B), and monocultural sicklepod (C) in 2012.

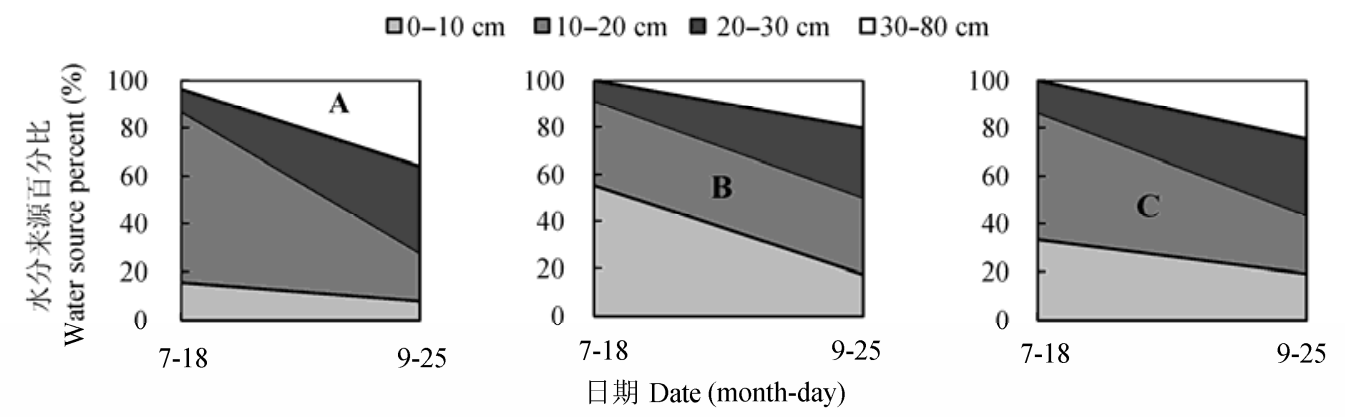

图142013年间作核桃(A)、间作决明(B)和单作决明(C)水分利用来源比例。

Fig. 14 Proportions of water sources for intercropped walnut (A), intercropped sicklepod (B), and monocultural sicklepod (C) in 2013.

这与Siriri等(2013)研究SW Uganda梯田上的几种农 林复合系统得出林农间作具有提高土壤水分的作用 的结论一致。同时, 相对单作果树, 药材的间作也保 持了复合系统树行中间部分的土壤水分, 因而复合 系统的土壤含水量也比单作果树高。在2013年, 果 药复合系统和单作果树地块的土壤含水量差异较 少，应该是由于干旱，复合系统内的土壤水分消耗 较多的缘故。垂直方向上, 表层土壤水分蒸发严重、 含水量较少。在水平方向上, 由于临近核桃树的位 置受到核桃遮阴保持水分, 因此此处土壤含水量较
大，尤其是在核桃树下和树行北侧，此处也是作物 吸水较少的区域; 相反, 位于树行中间位置的土壤 含水量则最低。

单作系统土壤水 $\delta \mathrm{D}$ 值比间作系统的偏正也正 是由于没有核桃树的遮阴，土壤水蒸发较强，水同 位素分馏较严重，氛同位素富集造成的，同样的原 因也造成在水平方向上复合系统中的土壤水的 $\delta \mathrm{D}$ 值呈现距离树行两边低、中间高的现象。核桃和菘 蓝/决明木质部/茎水的 $\delta \mathrm{D}$ 值差异是其水源不同造成 的, 核桃主要吸收 $\delta \mathrm{D}$ 值偏负的深层水, 而菘蓝和决 

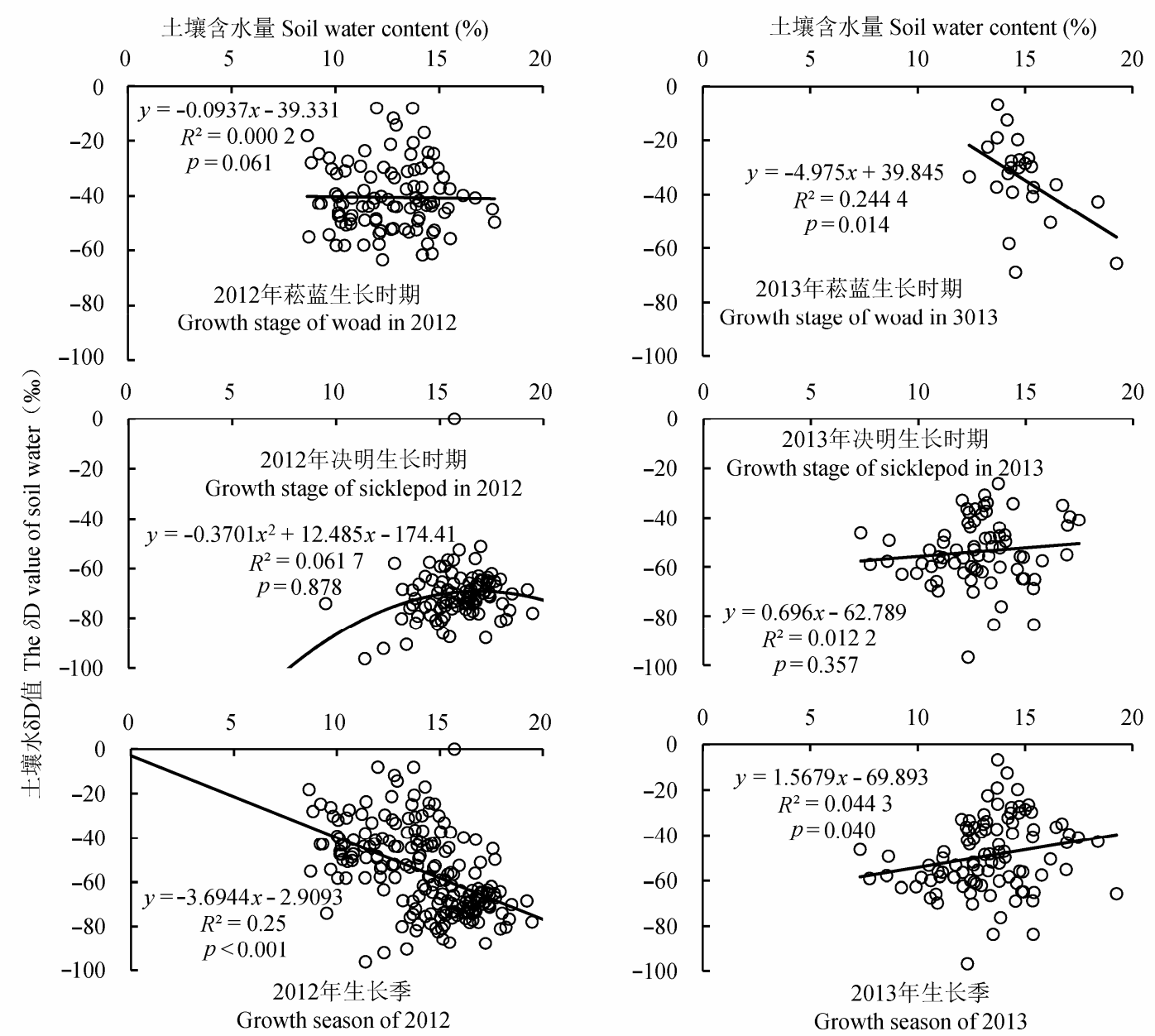

图152012和2013年土壤水分 $\delta \mathrm{D}$ 值与土壤含水量的相关关系。

Fig. 15 The correlations between $\delta$ D value of soil water and soil water content in 2012 and 2013.

明主要吸收 $\delta \mathrm{D}$ 值偏正的浅层水, 特别是在单作菘蓝/ 决明地块, 因而造成间作核桃 $\delta \mathrm{D}$ 值最小、间作菘蓝/ 决明居中、单作菘蓝/决明最偏正。

研究区的降雨量和雨水 $\delta \mathrm{D}$ 呈线性负相关关系。 但整个生长季的土壤水 $\delta \mathrm{D}$ 值与土壤含水量在 2012 年呈负相关关系、在2013年呈正相关关系。但在这 2 年中菘蓝生长时期, 两者均呈负相关关系、在决明 生长时期则均呈正相关关系。由于土壤水分蒸发会 产生土壤水氢氧同位素的分馏(Durand et al., 2007), 造成重同位素组成富集。因而降雨入渗到土壤中后 经过水分蒸发分馏会产生氢氧同位素的变化, 特别 是在炎热的夏季以及在干旱时, 土壤中気同位素更 加富集, 远偏离雨水的 $\delta \mathrm{D}$ 值。这些原因可能造成了 2013年(干旱)以及决明生长时期(高温)土壤水 $\delta \mathrm{D}$ 值 与土壤含水量反而呈正相关关系。

菘蓝主要集中生长在4-6月份的春旱时期, 空
气温度在不断升高, 而降水量较少, 土壤含水量较 低, 特别是表层土壤水分蒸发较多, 造成核桃吸水 根下移，因而核桃-菘蓝间作系统中核桃大部分的 水分来自于深层土壤水。而决明生长时期正值雨季, 雨水充分补给各层土壤水分, 表层土壤含水量较干 旱季节明显提高。因而核桃优先利用了浅层土壤水 或者直接吸收雨水, 表现为主要利用0-30 cm浅层 土壤水分。但随着决明生长后期土壤含水量的减少, 核桃吸水层则有所下移。这与Meinzer等(1999)的研 究结果一致, 即越是干旱季节植物越倾向于使用较 稳定的深层土壤水, 从而保持水分利用总量的稳定, 避免生存受到威胁。Zencich等(2002)发现, 当降水 量较少时, 在干旱地区的耐旱物种, 一般只使用深 层土壤水和地下水, 但当雨季来临之后, 植物的根 系能迅速地转为吸收表层土壤中的雨水。Williams 等(2000)将干旱和半干旱地区植物根系的这种吸水 
现象归为根系的二态性。核桃之所以能在雨季和旱 季利用不同深度的水分, 可能与其二态性根系有 关。核桃表层根系在旱季活性并不高, 深层根系为 核桃生长提供了主要的水分来源, 降水以后, 表层 根系活性增加, 才开始大量吸收表层土壤水分(孙 守家等, 2010)。这应该是核桃能适应当地干旱瘦薄 的环境条件的主要原因。

间作和单作系统中菘蓝和决明在各个时期均主 要利用来自0-30 $\mathrm{cm}$ 浅层土壤中的水分, 比例在 $85 \%$ 以上, 两者在干旱时吸收层则有所下移。 February等(2007)在热带稀树大草原对不同层次水 分利用的研究发现, 草本主要利用表层土壤水, 而 树木主要是利用深层土壤水。Sekiya和Yano (2004) 测定了农田混作的玉米和大豆对土壤水分的利用, 发现大豆多利用深层水分, 而玉米较多利用表层水 分。这些研究均表明水分来源的差异为复合系统中 不同物种间共存提供基础。

对于核桃-菘蓝复合系统, 菘蓝生长苗期, 菘蓝 根系尚未生长到深层土壤中, 单作菘蓝体内水分完 全来源于浅层土壤，但间作菘蓝在2012年却利用了 $5.7 \%$ 的深层土壤水, 在更为干旱的 2013 年该比例更 是上升到 $9.7 \%$ 。此时正值春旱, 这部分水分应该是 深根性的核桃通过“水分提升”作用，将深层土壤水 分提升并释放到浅层土壤而被菘蓝吸收利用。而在 雨水较多的决明苗期的生长则未发现其利用深层土 壤水的现象, 上述结果证实了间作核桃在旱季存在 “水力提升”作用(Sun et al., 2014), 也表明越是干旱, 核桃的“水力提升”作用越强。

在华北低丘山区核桃-菘蓝/决明复合系统中, 深根性核桃改善了复合系统中作物的土壤水分状 况, 在旱季主要利用深层土壤水避开与浅层作物的 水分竞争、并能将深层土壤水提升至浅层土壤供菘 蓝吸收利用; 而在雨季则转向利用雨水补充的浅层 土壤水为主, 两者在空间上充分利用水资源、避开 水分竞争。从核桃、菘蓝和决明的水分来源特征来 看, 核桃-菘蓝/决明配置模式中的各组分表现为互 利关系。除了水分上的互利, 间作作物的调落物也 能对核桃进行施肥作用, 间作的豆科植物决明也可 能会提高核桃对氮素的吸收利用, 这也需要对其种 间养分关系进行进一步研究。此外, 核桃能很好地 适应当地的干旱贫瘦的环境条件, 对丘陵山地具有 保持水分、防止水土流失、改善生态环境等生态功
能。同时，核桃果实和间作药材的收入也能提高农 民的经济收益, 复合系统的总体收益和产量土地当 量远高于单作系统(陈平等, 2014)。因而, 该模式兼 具生态和经济效益, 适合在该地区发展。

基金项目 国家自然科学基金(31170409)和中央级 公益性科研院所基本科研业务费专项 (RIF201308)。

致谢 感谢河南省济源市国有大沟河林场贾长荣和 任迎丰在取样中给予的帮助!

\section{参考文献}

Chen P, Meng P, Zhang JS, He CX, Jia CR, Li JZ (2014). Water use of intercropping system of tree and two herbal medicine in the low hilly area of North China. Journal of Northeast Forestry University, 42(8), 52-56, 78. [陈平, 孟平, 张劲松, 何春霞, 贾长荣, 李建中 (2014). 华北 低丘山区2种林药复合模式的水分利用. 东北林业大学 学报, 42(8), 52-56, 78.]

Durand JL, Bariac T, Ghesquière M, Biron P, Richard P, Humphreys M, Zwierzykovski Z (2007). Ranking of the depth of water extraction by individual grass plants, using natural ${ }^{18} \mathrm{O}$ isotope abundance. Environmental and Experimental Botany, 60, 137-144.

Ehleringer JR, Phillips SL, Schuster WSE, Sandquist DR (1991). Differential utilization of summer rains by desert plants. Oecologia, 88, 430-434.

February E, Higgins S, Bond W J (2007). Using stable water isotopes to determine the depth of water used by different sizes of savanna trees. South African Journal of Botany, 73, 287-292.

He CX, Meng P, Zhang JS, Gao J, Sun SJ (2012). Water use of walnut-wheat intercropping system based on stable carbon isotope technique in the low hilly area of North China. Acta Ecologica Sinica, 32, 2047-2055. [何春霞, 孟平, 张劲松, 高峻, 孙守家 (2012). 基于稳定碳同位素技术 的华北低丘山区核桃-小麦复合系统种间水分利用研究. 生态学报, 32, 2047-2055.]

Meinzer FC, Andrade JL, Goldstein G (1999). Partitioning of soil water among canopy trees in a seasonally dry tropical forest. Oecologia, 121, 293-301.

Nie YP, Chen HS, Wang KL (2011). Seasonal variation of water sources for plants growing on continuous rock outcrops in limestone area of Southwest China. Chinese Journal of Plant Ecology, 35, 1029-1037. (in Chinese with English abstract) [聂云鹏, 陈洪松, 王克林 (2011). 石灰岩地区 连片出露石丛生境植物水分来源的季节性差异. 植物 生态学报, 35, 1029-1037.]

Penna D, Oliviero O, Assendelft R, Zuecco G, Meerveld I, Anfodillo T, Carraro V, Borga M, Fontana GD (2013). 
Tracing the water sources of trees and streams: Isotopic analysis in a small pre-alpine catchment. Procedia Environmental Science, 19, 106-112.

Phillips DL, Gregg JW (2003). Source partitioning using stable isotopes: Coping with too many sources. Oecologia, 136, 261-269.

Rezig M, Sahli A, Ben jeddi F, Harbaoui Y (2013). Potato (Solanum tuberosum L.) and sulla (Hedysarum coronaruim L.) intercropping in Tunisia: Effects in water consumption and water use efficiency. Journal of Agricutural Science, 5(10), 123-136.

Rivest D, Cogliastro A, Bradley RL, Olivier A (2010). Intercropping hybrib poplar with soybean increses soil microbial biomass, mineral N supply and tree growth. Agroforestry System, 76, 513-523

Rose KL, Graham RC, Parker DR (2003). Water source utilization by Pinus jeffreyi and Arctostaphylos patula on thin soils over bedrock. Oecologia, 134, 46-54.

Sekiya N, Yano K (2004). Do pigeon pea and sesbania supply groundwater to intercropped maize through hydraulic lift? Hydrogen stable isotope investigation of xylem waters. Field Crops Research, 86, 167-173.

Sher AA, Wiegand K, Ward D (2010). Do Acacia and Tamarix trees compete for water in the Negev desert? Journal of Arid Environments, 74, 338-343.

Siriri D, Wilson J, Coe R, Tenywa MM, Bekunda MA, Ong CK, Black CR (2013). Trees improve water storage and reduce soil evaporation in agroforestry systems on bench terraces in SW Uganda. Agroforestry System, 87, 45-58.

Snyder KA, Williams DG (2000). Water sources used by riparian trees varies among stream types on the San Pedro River, Arizona. Agricultural and Forest Meteorology, 105, 227-240.

Sun SJ, Meng P, Zhang JS, Huang H, Wan XC (2010). Deute- rium isotope variation and water use in an agroforestry system in the rocky mountainous area of North China. Acta Ecologica Sinica, 30, 3717-3726. (in Chinese with English abstract) [孙守家, 孟平, 张劲松, 黄辉, 万贤崇 (2010). 华北石质山区核桃-绿豆复合系统氞同位素变 化及其水分利用. 生态学报, 30, 3717-3726.]

Sun SJ, Meng P, Zhang JS, Wan XC (2014). Hydraulic lift by Juglans regia relates to nutrient status in the intercropped shallow-root crop plant. Plant and Soil, 374, 629-641.

Wanvestraut RH, Jose S, Nair PKR, Brecke B (2004). Competition for water in a pecan (Carya illinoensis K. Koch)cotton (Gossypium hirsutum L.) alley cropping system in the southern United States. Agroforestry Systems, 60, 167179.

Williams DG, Ehleringer JR (2000). Intra- and inter-specific variation for summer precipitation use in pinyon-juniper woodlands. Ecological Monographs, 70, 517-537.

Xu Q, Ji CL, Wang HY, Li Y (2009). Use of stable isotopes of hydrogen, oxygen and carbon to identify water use strategy by plants. World Forestry Research, 22(4), 41-46. (in Chinese with English abstract) [徐庆, 冀春雷, 王海英, 李昒 (2009). 氢氧碳稳定同位素在植物水分利用策略 研究中的应用. 世界林业研究, 22(4), 41-46.]

Zencich SJ, Froend RH, Turner JV, Gailitis V (2002). Influence of groundwater depth on the seasonal sources of water accessed by Banksia tree species on a shallow, sandy coastal aquifer. Oecologia, 131, 8-19.

Zhang W, Ahanbieke P, Wang BJ, Lu WL, Li LH, Christie P, Li $\mathrm{L}$ (2013). Root distribution and interaction in jujube tree/wheat agroforestry system. Agroforestry System, 87, 929-939.

责任编委: 储诚进 责任编辑: 李 敏

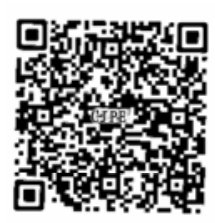

植物生态学报官网

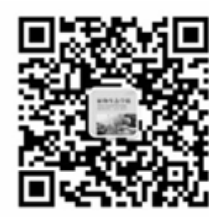

微信订阅号

期刊及学科

相关信息发布

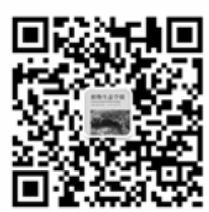

微信服务号

稿件状态查询

全文检索汶览 